\title{
Challenging energy balance
}

Citation for published version (APA):

Westerterp - Plantenga, M. (2018). Challenging energy balance. Maastricht University. https://doi.org/10.26481/spe.20180601mwp

Document status and date:

Published: 01/06/2018

DOI:

10.26481/spe.20180601mwp

Document Version:

Publisher's PDF, also known as Version of record

\section{Please check the document version of this publication:}

- A submitted manuscript is the version of the article upon submission and before peer-review. There can be important differences between the submitted version and the official published version of record.

People interested in the research are advised to contact the author for the final version of the publication, or visit the DOI to the publisher's website.

- The final author version and the galley proof are versions of the publication after peer review.

- The final published version features the final layout of the paper including the volume, issue and page numbers.

Link to publication

\footnotetext{
General rights rights.

- You may freely distribute the URL identifying the publication in the public portal. please follow below link for the End User Agreement:

www.umlib.nl/taverne-license

Take down policy

If you believe that this document breaches copyright please contact us at:

repository@maastrichtuniversity.nl

providing details and we will investigate your claim.
}

Copyright and moral rights for the publications made accessible in the public portal are retained by the authors and/or other copyright owners and it is a condition of accessing publications that users recognise and abide by the legal requirements associated with these

- Users may download and print one copy of any publication from the public portal for the purpose of private study or research.

- You may not further distribute the material or use it for any profit-making activity or commercial gain

If the publication is distributed under the terms of Article $25 \mathrm{fa}$ of the Dutch Copyright Act, indicated by the "Taverne" license above, 


\section{Maastricht University}

Prof. dr. Margriet WesterterpPlantenga

Faculty of Health, Medicine and Life Sciences

Challenging Energy Balance 


\section{Samenvatting \\ Afscheidsrede}

Challenging Energy Balance

I juni 2018

Prof. dr. Margriet Westerterp-Plantenga,

Challenging Energy Balance

I. Energiebalans

II. Uitdagingen van de energie-balans

Overgewicht en obesitas

III. Concepten voor behandeling van overgewicht en obesitas

IV. Het hoofd bieden aan uitdagingen van de energiebalans 


\section{Energiebalans}

Wanneer de energieinname precies voldoet aan de energiebehoefte, die bepaald wordt door het energiegebruik, is er sprake van een perfecte energiebalans, weerspiegeld in een constant lichaamsgewicht.

Wanneer de energieinname de energiebehoefte overschrijdt, ontstaat een positieve energiebalans, waarbij het surplus aan ingenomen energie wordt opgeslagen als lichaamsvet, en het lichaamsgewicht toeneemt. Dit houdt aan totdat er een nieuwe energiebalans onstaat, met een energiegebruik, energiebehoefte, en energieinname op een hoger niveau, bij een hoger lichaamsgewicht. Het hogere energiegebruik en daarmee de hogere energiebehoefte zijn het gevolg van de groter geworden lichaamsmassa die onderhouden moet worden, en actief moet zijn. Een herhaaldelijk optredende positieve energiebalans vergroot de kans op overgewicht en obesitas.

Regulatie van de energiebalans vergt een nauwkeurige afstemming van energieinname op energiegebruik, waarbij het continue karakter van het energiegebruik, en de discontinue energieinname deze afstemming compliceert. Deze afstemming vindt plaats in het brein, waar stofwisselingssignalen, zoals insuline, leptine, en de zogenaamde verzadigingshormonen GLP-I, PYY, CCK informative geven over de 
energiestatus van het lichaam. In het brein vindt niet enkel een energetische afweging plaats, maar spelen de 'belonende waarde' van het eten, zoals de smaak van het voedsel, de waardering voor de ambiance, en emoties een rol, alsook modulerende factoren, zoals de circadiane ritmiek, omgevingstemperatuur, en lichamelijke activiteit. Dat alles leidt in een fractie van een seconde tot de beslissing om bij de confrontatie met voedsel, te eten of niet. Samenvattend, regulatie van de energiebalans bestaat niet alleen uit een energetische afstemming, maar wordt tevens bepaald door de belonende waarde van het eten.

\section{Uitdagingen van de energiebalans}

Met onze gevoeligheid voor de belonende waarde van het eten, alsook onze 24/7 tijdbesteding, dagen we onze energiebalans uit. De invloed van de belonende waarde van het voedsel, stress, en een onregelmatig leefpatroon voor wat betreft lichamelijke activiteit voedselconsumptie en slaap, vergroten de kans op overgewicht en obesitas. 


\section{Overgewicht en obesitas}

Mondiaal heeft overgewicht en obesitas momenteel niveaus bereikt van $20 \%$ of minder in bijvoorbeeld India, Korea en Japan, tot $60 \%$ of meer in bijvoorbeeld Canada, Amerika, Argentinie, Het Verenigd Koninkrijk, landen rond de Middellandse zee, en Australie.

\section{Concepten voor behandeling van overgewicht en obesitas}

Vigerende behandel methoden voor overgewicht en obesitas zijn maagverkleining, farmacologische middelen zoals in Europa orlistat, liraglutide, buproprion+naltrexon, en leefstijlprogramma's, bestaande uit energieinname restrictie, vergezeld van een voedselconcept, maaltijdpatroon, lichamelijke activiteit, slaap, en een circadiaan ritme in overeenstemming met het individuele biologische ritme.

De focus ligt hier op energieinname restrictie, vergezeld van een voedselconcept. Gezien de redundantie van de regulatie van de energiebalans, dient, tijdens restrictie van de energieinname, een relevant voedselconcept aan diverse factoren te voldoen, Het dient de stofwisselingssignalen uit het lichaam zodanig te beïnvloeden dat in wanneer minder wordt gegeten dan voorheen teneinde af te vallen, toch 
het gebruikelijke niveau van verzadiging wordt ervaren. Voorts dient het, om het jo-jo-effect te voorkomen, het energiegebruik dat bij een slinkende lichaamsmassa afneemt, toch op het oorspronkelijke niveau te houden, en daarbij de vetoxidatie te stimuleren, en de vetvrije massa (de organen en spieren die grotendeels het energiegebruik bepalen) te sparen. Daarnaast moet onderzocht worden wat het effect van het voedselconcept op de belonende waarde van het voedsel is. Diverse voedselconcepten, zoals laag-vet dieten, catechinen in groene thee, capsaicine in rode peper, vezel, en eiwitten zijn, tijdens energierestrictie onderzocht, en deze leverden allemaal een resultaat op op basis van enkele van de gestelde voorwaarden.

Mijns inziens het meest interessante resultaat werd getoond met relatief hoog-eiwit dieten. Deze bestaan uit een constante eiwitinname, op het niveau dat men gewend was (dagelijks 0,8 - I,2 g/kg lichaamsgewicht), terwijl de koolhydraat- en vetinname worden gereduceerd, waarmee de totale energieinname wordt gereduceerd. Wij hebben aangetoond dat een dergelijk eiwit-dieet een grotere daling in lichaamsgewicht laat zien dan een controle dieet, en een sterker behoud van het verkregen lagere lichaamsgewicht tot ten minste 2 jaar na de start. Dit bleek inderdaad gebaseerd te zijn op de factoren verzadiging en energiegebruik, die op het oorspronkelijke niveau waren gebleven, de gespaard gebleven vetvrije massa, en de toegenomen vetoxidatie. Echter, wat betreft de 
belonende waarde, bleek een dergelijk eiwit-dieet wel te voorzien in de voedselbehoefte, maar te weinig in het lekker vinden van het voedsel: de voorkeur voor koolhydraten was toegenomen. Daarmee wordt de energiebalans opnieuw uitgedaagd.

\section{Het hoofd bieden aan uitdagingen van de energie-balans}

In onze huidige studie, een Europese multicenter studie genaamd PREVIEW:

'PREVention of diabetes through lifestyle Intervention and population studies in Europe and around the World', met deelnemers met een verminderde glucose tolerantie, dus grotere kans op type II diabetes, namen we het volgende waar. $\mathrm{Na}$ twee maanden afvallen, en vervolgens een jaar en twee maanden op een gemiddeld- tot hoog-eiwit, energiebeperkt dieet hadden de deelnemers hun verkregen, lagere lichaamsgewicht behouden. Hier bleek naast genoemde effecten van een eiwit-dieet tijdens energierestrictie, zogeheten 'beheerst eetgedrag' een doorslaggevende rol te spelen. $\mathrm{Zij}$ die het hoogst scoorden op bewuste beheersing van hun eetgedrag, bestaande uit maaltijdpatroon, voedselkeuze en voedselhoeveelheid, bleken het sterkst hun lichaamsgewicht te beheersen, terwijl hun insuline gevoeligheid was 
toegenomen. Hlermee was tevens een grotere beheersing ten aanzien van signalering van de belonende waarde van het eten in het brein geassocieerd.

\section{Conclusies}

Regulatie van de energiebalans bestaat niet alleen uit een energetische afstemming, maar wordt tevens bepaald door de belonende waarde van het eten. De energiebalans wordt uitgedaagd door onder meer gevoeligheid voor de belonende waarde van het voedsel, stress, en circadiane asynchronisatie. Hiermee neemt de kans op overgewicht en obesitas toe.

Een relatief hoog-eiwit energiebeperkt dieet is, als onderdeel van een leefstijl programma, een interessant voedselconcept voor de behandeling van overgewicht en obesitas, gebaseerd op zijn multifactoriele effecten. Daarbij biedt beheerst eetgedrag het hoofd aan uitdagingen van de energiebalans. 